\title{
CHAPTER 8 \\ METHODOLOGY AND PRACTICE OF THE ADAPTABILITY EVALUATION OF THE NATIONAL ECONOMY TO THE EXTERNAL CONDITIONS CHANGE
}

Kononova I. V.

\section{INTRODUCTION}

Modern economic relations are characterized by the acceleration of transformation processes, which makes new demands for socioeconomic systems at different levels of the hierarchy. Nowadays, changes are happening quite dynamically, creating conditions of the increased uncertainty and new threats. In such circumstances, functioning and development of the socio-economic systems requires to be more adaptable, which will allow to successfully resist the emerging threats.

Research in the national economy of the manifestations of chaotic dynamics, as well as the event detection of catastrophic nature associated with sudden abrupt changes in the environment, the influence of uncertainties and irregularities prove the lack of effectiveness of the use of classical methods and models in this situation. So, there is the urgent need to find the ways to adapt to the changing conditions of functioning of the national economy.

The problem of adaptation of socio-economic systems to the environmental conditions and ensuring their adaptability had been considered by foreign and domestic scientists-economists. Among them are: I. Pitaykin, O. Pastukhov, V. Yachmenova, G. Hanaliyev, A. Maksimovich, D. Chuiko, V. Fomin and many others.

Despite the value of the research results conducted by scientists, it should be noted that some methodological aspects of the adaptability of the national economy require clarification and practical testing.

\subsection{The essence of adaptability as an economic category}

The presence of a significant reaction of the national economy to changing environmental variability causes the need to determine the degree of adaptability of the national economy to changing conditions of the external environment. 
First of all, it is necessary to determine from the point of view of modern scientific researches the definition of the term «adaptability».

The term adaptability (from the Latin «adaptio» - adaptation) was first introduced in the biology. Dissemination of this term in the systems theory requires the need to find the ways to adapt systems of different order to the changing conditions of their functioning.

Adaptability is a property of the system that stems from its openness. Openness means sensitivity to external impulses and provides feedback to the environment. The mechanism of implementation of adaptation is intended to make the system most adapted to the environment. This task involves adjusting the optimal balance between the internal capabilities of the system and the external requirements of the environment. Against this background, we should focus on defining the concept of «adaptation».

According to the American Encyclopedia, adaptation is a shift in the function or the form (structure) of the system's existence in the particular sphere.

Modern economic vocabulary interprets adaptation as the adaptation of economic systems and its individual subjects, workers to the environmental conditions, production, labor, exchange, and changing lives ${ }^{1}$.

Scientists also give different definitions to this concept. The main approaches to defining the term «adaptation» by various scholars are given in the Table 1 .

Therefore, in any sense, the concept of adaptation would not be considered, it is always some change, the ultimate goal of which is to ensure the effective functioning of the system in new conditions. The keywords in the definition of a concept are both process, shift, adaptation, mechanism, ability, as well as qualitative trait.

So, in spite of the variety of definitions, in our opinion, existing interpretations can be conditionally combined into the following approaches to the essence of the concept of «adaptation»:

- adaptation as the adaptation to certain conditions or changes (V. Kaznacheev, S. Chyzhenkov, I. Pitaykin, V. Yachmeniova, A. Sudarev, B. Reizberg, L. Lozovsky, O. Starodubtseva, V. DanilovDanilyan);

- adaptation as the change under the influence of certain factors (T. Lastayev, A. Kaygorodtsev, O. Pastukhov, G. Kozachenko);

\footnotetext{
${ }^{1}$ Rayzberg B.A., Lozovskiy L.Sh., Starodubtseva E.B. (2006). Sovremennyiy ekonomicheskiy slovar [Modern economic dictionary]. Moskva: Infra-M, 564 p.
} 
Table 1

Approaches to defining the concept of «adaptation» by various scholars

\begin{tabular}{|c|c|c|c|}
\hline \multirow{2}{*}{ Authors } & \multicolumn{3}{|c|}{ Approaches to the definition } \\
\hline & As the action & As the impulse & As the focus \\
\hline 1 & 2 & 3 & 4 \\
\hline V. Kaznacheyev [1] & $\begin{array}{l}\text { Adaptation to } \\
\text { living } \\
\text { conditions }\end{array}$ & $\begin{array}{l}\text { Change of } \\
\text { living } \\
\text { conditions }\end{array}$ & $\begin{array}{l}\text { Saving, } \\
\text { developing, } \\
\text { achieving the } \\
\text { main goal of } \\
\text { the progress }\end{array}$ \\
\hline $\begin{array}{l}\text { T. Lastayev, } \\
\text { A. Kaygorodtsev [2] }\end{array}$ & $\begin{array}{l}\text { Change in } \\
\text { parameters, } \\
\text { structure and } \\
\text { properties of } \\
\text { the system }\end{array}$ & $\begin{array}{l}\text { Influence of } \\
\text { external and } \\
\text { internal factors }\end{array}$ & $\begin{array}{l}\text { Effective } \\
\text { functioning of } \\
\text { the system } \\
\text { and its } \\
\text { elements }\end{array}$ \\
\hline I. Miloslavova[3] & $\begin{array}{l}\text { Interference } \\
\text { with the } \\
\text { environment }\end{array}$ & $\begin{array}{l}\text { Dynamism of } \\
\text { the external } \\
\text { environment }\end{array}$ & $\begin{array}{l}\text { Successful } \\
\text { functioning }\end{array}$ \\
\hline Y. Chyzhenkova [4] & $\begin{array}{l}\text { Adaptation of } \\
\text { business entity } \\
\text { parameters }\end{array}$ & $\begin{array}{l}\text { Uncertainty } \\
\text { of } \\
\text { environmental } \\
\text { conditions }\end{array}$ & $\begin{array}{l}\text { Increase in } \\
\text { functioning } \\
\text { efficiency }\end{array}$ \\
\hline I. Pitaykina [5] & $\begin{array}{l}\text { Adaptation of } \\
\text { organizational- } \\
\text { economic and } \\
\text { socio- } \\
\text { economic } \\
\text { relations }\end{array}$ & - & $\begin{array}{l}\text { Effective use } \\
\text { of property } \\
\text { and } \\
\text { strengthening } \\
\text { of social } \\
\text { orientation }\end{array}$ \\
\hline O. Pastukhova [9] & Modifications & - & Survival \\
\hline V. Yachmen'ova[4] & $\begin{array}{l}\text { Adaptation of } \\
\text { the system }\end{array}$ & $\begin{array}{l}\text { New system } \\
\text { functioning } \\
\text { conditions }\end{array}$ & - \\
\hline G. Kozachenko [8] & Changes & - & Security \\
\hline G. Hanaliyev [9] & $\begin{array}{l}\text { Mechanism of } \\
\text { regulation }\end{array}$ & $\begin{array}{l}\text { External } \\
\text { factors }\end{array}$ & $\begin{array}{c}\text { Saving } \\
\text { (change) of } \\
\text { direction and } \\
\text { pace of } \\
\text { development }\end{array}$ \\
\hline
\end{tabular}


Continuation of the Table 1

\begin{tabular}{|c|c|c|c|}
\hline A. Sudarev [6] & $\begin{array}{c}\text { Adaptation of } \\
\text { legal norms }\end{array}$ & $\begin{array}{c}\text { Changes in } \\
\text { the } \\
\text { environment }\end{array}$ & - \\
\hline $\begin{array}{c}\text { B.Reisberg,L.Lozovsky, } \\
\text { O. Starodubtseva[4] }\end{array}$ & $\begin{array}{c}\text { Adaptation of } \\
\text { economic } \\
\text { systems and } \\
\text { individual } \\
\text { entities }\end{array}$ & $\begin{array}{c}\text { Conditions of } \\
\text { external and } \\
\text { internal } \\
\text { environment }\end{array}$ & - \\
\hline V. Danilov- & $\begin{array}{c}\text { Adaptation in } \\
\text { complex } \\
\text { Danilyan [5] }\end{array}$ & - & - \\
\hline
\end{tabular}

Source: created by the author, based upon [1-9]

- adaptation in response to certain changes in the form of regulation or intervention (I. Miloslavova, G. Khanaliyev).

As we can see, most authors are inclined to use the very first approach, defining adaptation as the adaptation to certain conditions or factors (most often, external ones). In our opinion, this approach most accurately reflects the essence of adaptation. Thus, when using the concepts of change, intervention, regulation to reveal the essence of the concept of «adaptation» requires certain clarifications, additions, because not all of the changes, interventions or regulation indicate adaptation of the system.

At the same time, the adjustment has several interpretations mastering in certain conditions due to the acquisition of certain traits, skills, abilities; getting used to a new, unfamiliar environment, unusual conditions; bringing their actions and behavior into line with anything; coordination of their actions in certain conditions; changing, acquiring new forms, features, qualities depending on the circumstances, environment. As we can see from the above aspects of defining the essence of the concept of «adjustment», this term most accurately reflects the essence of the concept of «adaptation».

Scientists attribute the impulse to adaptation to the action of external factors or conditions or their change (T. Lastayev, A.Kaygorodtsev, V. Yachmeniova, G. Khanaliyev, A. Sudarev), conditions of the external and internal environment (B.Raisberg, L. Lozovsky, O. Starodubtseva), changing conditions of existence 
(V. Kazantsev), dynamism of the external environment (I. Miloslavov) or uncertainty (S. Chyzhenkov).

Different scientists have different opinions of the focus of adaptation. V. Kazaevayev reckons that adaptation is directed to preservation, development, achievement of the main goal of progress, T. Lastayev, A. Kaygorodtsev - to the effective functioning of the system and its elements, I. Miloslavova - to successful functioning, S. Chizhenkov - to increase of the functioning efficiency, I. Pitaykin - to the efficiency of the property use and strengthening of the social orientation, O. Pastukhov - to survival, G. Kozachenko - to security, and G. Khanaliyev - to preservation (change of directions and rates of development).

Based on the above approaches to the definition of adaptation, it can be argued that adaptability implies the ability to respond promptly in the course of the system's functioning to the current information coming about changes in its functioning conditions. The essence of the concept of adaptability is to change the parameters, structure and algorithms of the system's operation based on not only a priori information, but also current, as well as predicted information, in order to achieve or maintain the certain efficiency of the system when its conditions change.

So, unlike adaptation, the key to defining adaptability is property, response, ability, characterization.

Adaptability is closely linked to the availability of adaptive capabilities, which, in the context of socio-economic systems theory, can be defined as the resilient resistant characteristics of the national economy, which ensure its ability to adapt successfully to diverse environmental changes as it guides its development. The presence of adaptive capabilities of the national economy, their size determines the range of environmental factors to which the system can adapt.

When it comes to the adaptability of the national economy, it means the following:

1) national economy operates in the presence of the adequate response to uncertain or variable conditions;

2) national economy operates on the basis of the information received about these conditions and forms the ability to analyze them;

3) national economy immediately responds to the information to change the direction of its functioning.

A. Brichko reckons that in the course of the adaptability evaluation it is necessary to pay attention to the degree of response to internal challenges, the speed of changes in the management in the initial stages. 
He proposed the cybernetic model for adaptation evaluation based on the model of «market adaptation» of the enterprise ${ }^{2}$.

$\mathrm{K}$. Orlova reckons that adaptability is a complex indicator of the enterprise's ability to respond to fluctuations in environmental factors. She offers the evaluation of adaptability of the enterprise state in the following areas: external, marketing, resource, financial, organizational and management. The adaptability coefficient is an integral evaluation of the internal environment of the enterprise, its ability to introduce changes in order to adapt to the external environment ${ }^{3}$.

V. Tkachenko, E. Smirnov, V. Nerubatsky consider that the limits of the system adaptability should be based on the use of such indicators as the number of perturbations per unit time or the cycle of perturbations entering the system.

M. Starikova proposes to base the evaluation of the adaptability (stability) of the branches of the national economy on XYZ analysis, based on the calculation of the coefficient of variation, which reflects the degree of volatility of the studied trait. She proposed the hypothesis that the volatility of economic indicators of industries characterizes their adaptability to the transformation of the environmental conditions ${ }^{4}$.

$\mathrm{V}$. Yachmeniova proposes to use the system of indicators which makes it possible to evaluate adaptability on the basis of a number of integrated characteristics, such as: internal and external reserves of adaptability. Internal adaptability reserves are determined by the aggregate providing, and external adaptive reserves are determined by the aggregate of supporting factors. Adaptability, as the characteristic of the economic system, this author proposes to evaluate using the theory of fuzzy set using the method of fuzzy logic and to reflect the corresponding function of membership ${ }^{5}$.

There are two groups of indicators in the methodology of estimation of adaptability proposed by A. Maksimovich: according to the estimation of the adaptability of the organizational structure, consisting of four indicators and the evaluation of special conditions of

\footnotetext{
${ }^{2}$ Lastaev T.T. (2006). Mehanizm agropromyishlennoy integratsii [The mechanism of agricultural integration]. Vestnik KASSU, no. 4, pp. 10-12.

Chizhenkova E.V. (2006). Formirovanie ekonomicheskogo mehanizma adaptatsii hozyaystvuyuschego sub'ekta k ryinochnoy srede: avtoref. dis. ... kand. ekon. nauk : spets. 08.00.01 «Ekonomicheskaya teoriya» [Formation of an economic mechanism for the adaptation of an economic entity to a market environment: author. dis. ... cand. econ. Sciences: special. 08.00.01 "Economic Theory"]. Moskva, $24 \mathrm{p}$.

4 Yachmeneva V.M. (2008). Ponyatie «adaptatsiya» i «adaptivnost»: shodstvo i razlichie [The concepts of "adaptation" and "adaptability": similarities and differences]. Nauchnyiy vestnik Poltavskogo universiteta potrebitelskoy kooperatsii Ukrainyi, no. 1 (26), pp. 97-103.

${ }^{5}$ Hanaliev G.I. (2005). Adaptatsionnyiy protsess avtotransportnyih predpriyatiy [Adaptation process of motor transport enterprises. Stavropol]. Dep. VINITI RAN, № 1122-V, pp. 115-121.
} 
development, two or three indicators, at the discretion of experts. It offers a matrix of the level of adaptability of the city's industry structure, based on the evaluation of the main parameters that influence the adaptability of the structure: level of diversification of the economic structure; magnitude of the agglomeration effect (indirectly determined by the population of the city); degree of conjuncture of the leading branches of specialization and the level of income of the population. In addition, specific development conditions, such as the unique economic and geographical position or special administrative status of the city, which entails redistribution in favor of the city's financial resources, are identified by the expert way ${ }^{6}$.

O. Pastukhov in his methodology proposes to use three groups of indicators (there are eleven indicators at most), which reflect the stability of the system (three indicators), adaptability of the system (four indicators), dependence of the system on the environment (four indicators). In the complex internal structure of the concept it is possible to distinguish the functional and process components that characterize the essence of adaptability, to which O. Pastukhov attributes the following essential elements of the life of economic systems: first, adaptive features that ensure the survival of systems in specific environmental conditions; second, the adaptability caused by the whole organization of economic systems; third, adaptation processes that transform socio-economic systems, their subsystems, elements and individual adaptation traits depending on changes in the environmental conditions ${ }^{7}$.

Adaptive traits are qualitative characteristics inherent in the socioeconomic system that enable them to function effectively in the aggressive environment.

V. Andreev, V. Kobzev, S. Kostornichenko consider adaptability only from the point of view of the human factor, as making the managerial decision. In their opinion, adaptability of the economic system is calculated by two indicators, which is the ratio of the number of executives with a high level of independent thinking to the total number of executives in the enterprise 8910 .

\footnotetext{
${ }^{6}$ Lastaev T.T. (2006). Mehanizm agropromyishlennoy integratsii [The mechanism of agricultural integration]. Vestnik KASSU, no. 4, pp. 10-12.

Yachmeneva V.M. (2008). Ponyatie «adaptatsiya» i «adaptivnost»: shodstvo i razlichie [The concepts of "adaptation" and "adaptability": similarities and differences]. Nauchnyiy vestnik Poltavskogo universiteta potrebitelskoy kooperatsii Ukrainyi, no. 1 (26), pp. 97-103.

${ }^{8}$ Miloslavova I.A. (1974). Ponyatie i struktura sotsialnoy adaptatsii : avtoref. dis. ... kand. fil. nauk: spets. 09.00.00 «Sotsialnaya filosofiya» [The concept and structure of social adaptation: author. dis. ... cand. Phil. Sciences: special. 09.00.00 «Social Philosophy»]. Leningrad, 24 p.
} 
T. Shkilna, V. Pakhomov and L. Pechena propose to calculate the adaptability index by the four indicators and their derivatives: market share, sales, enterprise profit and investment volume. In this case, performance indicators are preferred, which significantly reduces the evaluation of prospects ${ }^{11}$.

According to I. Pitaikina, adaptability of the enterprise is better to assess expertly, not engaged in formalization and comparison of quantitative and qualitative indicators of the system. I. Pitaikina believes that adaptability of the organization as the organizational property characterizes the degree of adaptability of functionaries in the joint interaction of its employees ${ }^{12}$.

V. Stasyuk notes that the adaptive properties of the enterprise provide more effective reaction to the change in the conditions of realization of the goals, providing the conditions for maintaining equilibrium and stability. One of the main approaches to determining the optimal depth of enterprise adaptability is based on the calculation of the optimal field of maneuvering of the strategic plan of enterprise development.

Under the field of maneuvering, V. Stasiuk understands the amount of reserves that the system has when adjusting of the plan of its functioning. When calculating the plan that has adaptive properties, it is necessary to distinguish between two types of reserves: direct and indirect. In his view, direct reserves are the presence of surpluses that will be required when adjusting the production plan, indirect reserves represent the amount of surplus that, if possible, when adjusting the plan would provide maximum satisfaction of demand for them, and the threat of increasing costs through reserves would be minimal ${ }^{13}$.

\footnotetext{
9 Chizhenkova E.V. (2006). Formirovanie ekonomicheskogo mehanizma adaptatsii hozyaystvuyuschego sub'ekta k ryinochnoy srede: avtoref. dis. ... kand. ekon. nauk : spets. 08.00.01 «Ekonomicheskaya teoriya» [Formation of an economic mechanism for the adaptation of an economic entity to a market environment: author. dis. ... cand. econ. Sciences: special. 08.00.01 "Economic Theory"]. Moskva, 24 p.

${ }_{10}$ Pitaykina I.A. (2006). Zakonomernosti razvitiya gosudarstvennyih unitarnyih predpriyatiy Rossii v ryinochnoy ekonomike: avtoref. dis. ... kand. ekon. nauk : spets. 08.00.01 «Ekonomicheskaya teoriya» [Patterns of development of state unitary enterprises of Russia in a market economy: author. dis. ... cand. econ. Sciences: special. 08.00.01 "Economic Theory"]. Penza, 23 p.

${ }_{11}$ Yachmeneva V.M. (2008). Ponyatie «adaptatsiya» i «adaptivnost»: shodstvo i razlichie [The concepts of "adaptation" and "adaptability": similarities and differences]. Nauchnyiy vestnik Poltavskogo universiteta potrebitelskoy kooperatsii Ukrainyi, no. 1 (26), pp. 97-103.

${ }_{12}$ Pitaykina I.A. (2006). Zakonomernosti razvitiya gosudarstvennyih unitarnyih predpriyatiy Rossii v ryinochnoy ekonomike: avtoref. dis. ... kand. ekon. nauk : spets. 08.00 .01 «Ekonomicheskaya teoriya» [Patterns of development of state unitary enterprises of Russia in a market economy: author. dis. ... cand. econ. Sciences: special. 08.00.01 "Economic Theory"]. Penza, 23 p.

13 Kozachenko G.V. Ponomarov V.P., Lyashenko O.M. (2003). Ekonomicheskaya bezopasnost predpriyatiya: suschnost i mehanizm obespecheniya: monografiya [The economic security of the enterprise: the nature and mechanism of support: a monograph]. Kiev: Libra, 280 p.
} 
A similar view is presented in the source ${ }^{14}$

Most of the described approaches use complex and vague indicators that are not clearly formalized, and cause a rather loose interpretation of their meaning. In addition, often indicators are determined not only analytically but also expertly, which significantly reduces the reliability of the calculations.

We propose the approach to the adaptability evaluation that, unlike others, is based on the use of reactivity and reaction time indices, allowing not only to identify the ability of the national economy to resist threats and to use opportunities, speed of adaptation to negative and positive changes, but also to give an integrative adaptability evaluation of the national economy to the influence of changing environmental factors.

Methodological approach to the adaptability evaluation of the national economy to environmental changes is shown in Figure 1.

At the same time, it is worth considering the choice of appropriate methods for assessing the adaptability of the national economy. Having studied different methods, we came to the conclusion that the most appropriate is the combination of two groups of methods. These are economic-mathematical and statistical methods. Among the statistical methods, it is proposed to use an index method that will not only determine the adaptability indices according to the selected evaluation criteria, but also to summarize them in the aggregate index due to the comparability of the obtained values.

At the same time, the indices themselves (the indicators used for their calculation) are based on the results of economic and mathematical modeling using correlation-regression and variational analysis.

First of all, it is necessary to define criteria for assessing the adaptability of the national economy to the impact of changes in the external environment (positive, creating additional opportunities and negative, creating additional threats).

As such criteria we propose to use reactivity and reaction time. Reactivity is characterized by the ability to counter threats and take advantage of the opportunities that have arisen. Regarding reaction time, it is proposed to characterize the rate of adaptation to positive and negative changes.

It is proposed to calculate partial indicators for each of the adaptability evaluation criteria.

\footnotetext{
${ }^{14}$ Hanaliev G.I. (2005). Adaptatsionnyiy protsess avtotransportnyih predpriyatiy [Adaptation process of motor transport enterprises. Stavropol]. Dep. VINITI RAN, № 1122-V, pp. 115-121.
} 


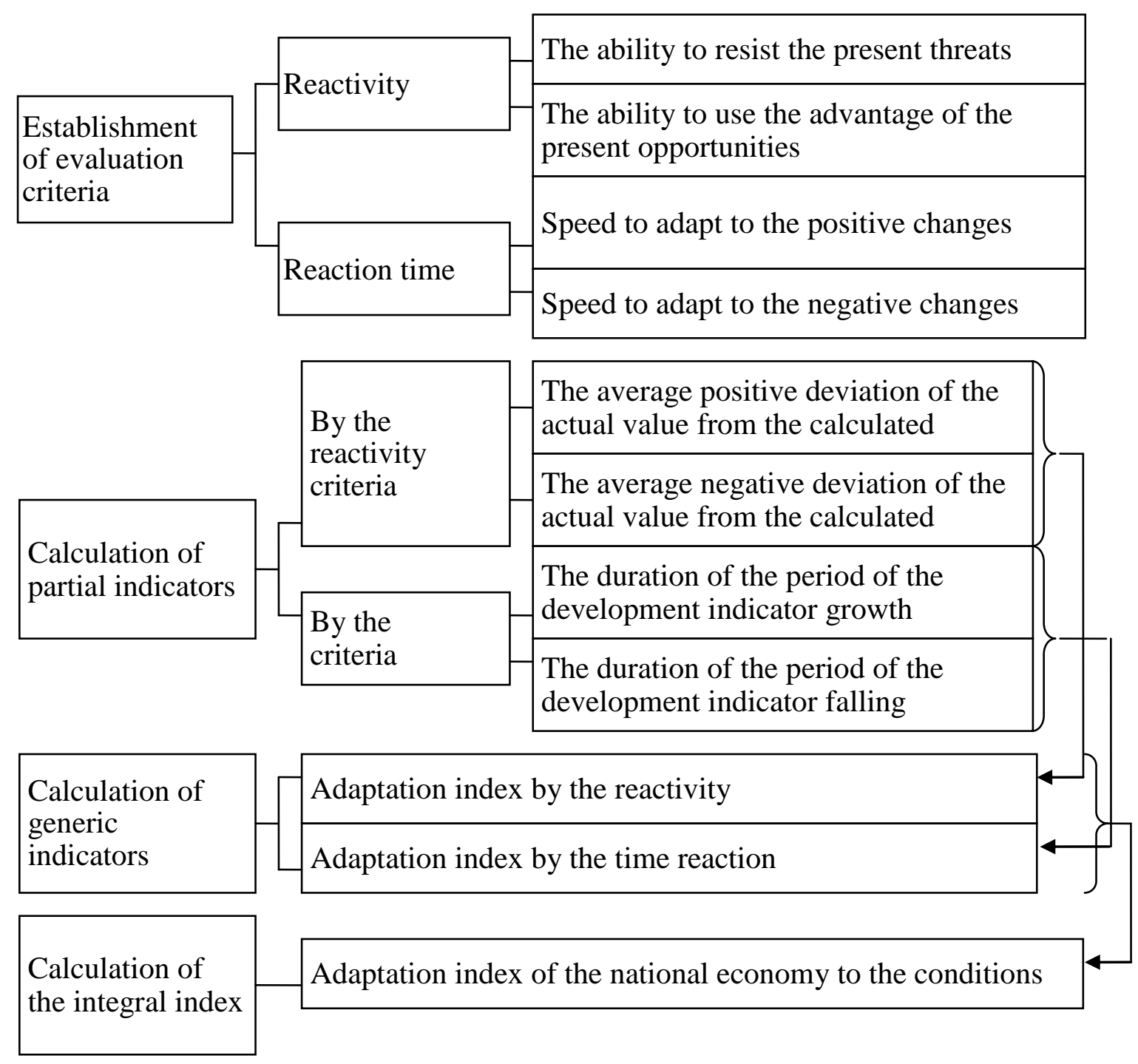

\section{Figure 1. Methodical approach to the adaptability evaluation of the national economy to the changes in the environment}

Source: created by the author

According to the reactivity criteria it is proposed to determine the average positive deviation of the actual value of the integral index of development of the national economy from the estimated one, as well as the average negative deviation of the actual value of the integral indicator of the development of the national economy from the calculated one. At the same time, it is proposed to determine the calculated value of the integral indicator of the development of the national economy on the basis of the function of the dependence of the development indicator on the indicator of environmental variability. 


\subsection{Practice of the adaptability evaluation of the national economy to the external conditions changing}

The estimated value of the integral indicator of the development of the national economy (national economy) is shown in Table 2.

\section{Estimated value of the integral indicator of national economy development}

\begin{tabular}{|c|c|}
\hline Year & Estimated value of the integral indicator of development \\
\hline 2011 & 0,163 \\
\hline 2012 & 0,214 \\
\hline 2013 & 0,242 \\
\hline 2014 & 0,237 \\
\hline 2015 & 0,228 \\
\hline 2016 & 0,201 \\
\hline 2017 & 0,183 \\
\hline 2018 & 0,175 \\
\hline
\end{tabular}

Source: created by the author

The average positive deviation of the actual value from the calculated value is determined by the formula:

$$
\Delta X_{S E E}^{+}=\sqrt{\frac{\sum_{t=1}^{n}\left(X_{S E E t}^{a c t}-X_{S E E t}^{c a l c}\right)^{2} \cdot \alpha_{t}}{T^{+}}},
$$

where $\Delta X_{S E E}^{+}$- average positive deviation of the actual value of the integral indicator of the development of the national economy from the calculated value of this indicator;

$X_{S E E t}^{a c t}-$ actual value of the integral indicator of the development of the national economy;

$X_{S E E t}^{\text {calc }}$ - calculated value of the integral indicator of the development of the national economy, which corresponds to the certain level of variability of the external environment;

$\alpha_{t}$ - parameter of choosing the actual values of the integral indicator of the development of the national economy for a certain year, which are greater than the estimated ones;

$t$ - period number;

$T$ - total number of years, of the analyzed period;

$T^{+}$- number of years of the analyzed period in which the actual values of the integral indicator of the national economy development exceed the estimated ones. 
The parameter of choice of the actual values of the integral index of development of the national economy for the certain year, which exceeds the calculated ones, can take the following values:

$$
\alpha_{t}=\left\{\begin{array}{l}
1, \text { if } X_{S E E t}^{a c t}>X_{S E E t}^{c a l c} \\
0, \text { if } X_{S E E t}^{a c t} \leq X_{S E E t}^{c a l c}
\end{array}\right.
$$

The higher the value of the average positive deviation of the actual value of the integral indicator of the development of the national economy from the calculated value of this indicator, the higher the ability of the national economy to use the opportunities that have arisen as the result of changes in the conditions of the system functioning.

The average negative deviation of the actual value from the calculated one is determined by the formula:

$$
\Delta X_{S E E}^{-}=\sqrt{\frac{\sum_{t=1}^{n}\left(X_{S E E t}^{a c t}-X_{S E E t}^{c a l c}\right)^{2} \cdot \beta_{t}}{T^{-}}},
$$

where $\Delta X_{S E E}^{-}$- average negative deviation of the actual value of the integral indicator of the development of the national economy from the calculated value of this indicator;

$X_{S E E t}^{a c t}-$ actual value of the integral indicator of the development of the national economy;

$X_{S E E t}^{\text {calc }}$ - calculated value of the integral indicator of the development of the national economy, which corresponds to the certain level of variability of the external environment;

$\beta_{t}$ - parameter of choosing the actual values of the integral indicator of the development of the national economy for a certain year, which are less than the estimated ones;

$t$ - period number;

$T^{-}$-total number of years, of the analyzed period;

$T^{-}-$number of years of the analyzed period in which the actual values of the integral indicator of the development of the national economy are less than estimated.

The parameter of choice of the actual values of the integral index of development of the national economy for a certain year, which are less than the estimated ones, can take the following values:

$$
\beta_{t}=\left\{\begin{array}{l}
0, \text { if } X_{S E E t}^{a c t}>X_{S E E t}^{c a l c} \\
1, \text { if } X_{S E E t}^{a c t} \leq X_{S E E t}^{c a l c}
\end{array}\right.
$$


The smaller the value of the average negative deviation of the actual value of the integral indicator of the development of the national economy from the calculated value of this indicator, the higher the ability of the national economy to resist threats that arise as a result of changes in the conditions of the system functioning.

The table for calculating the average positive deviation of the actual value of the integral development indicator is presented below.

Table 3

Table for the calculation of the average positive and negative deviation of the actual value of the integral development indicator from the calculated

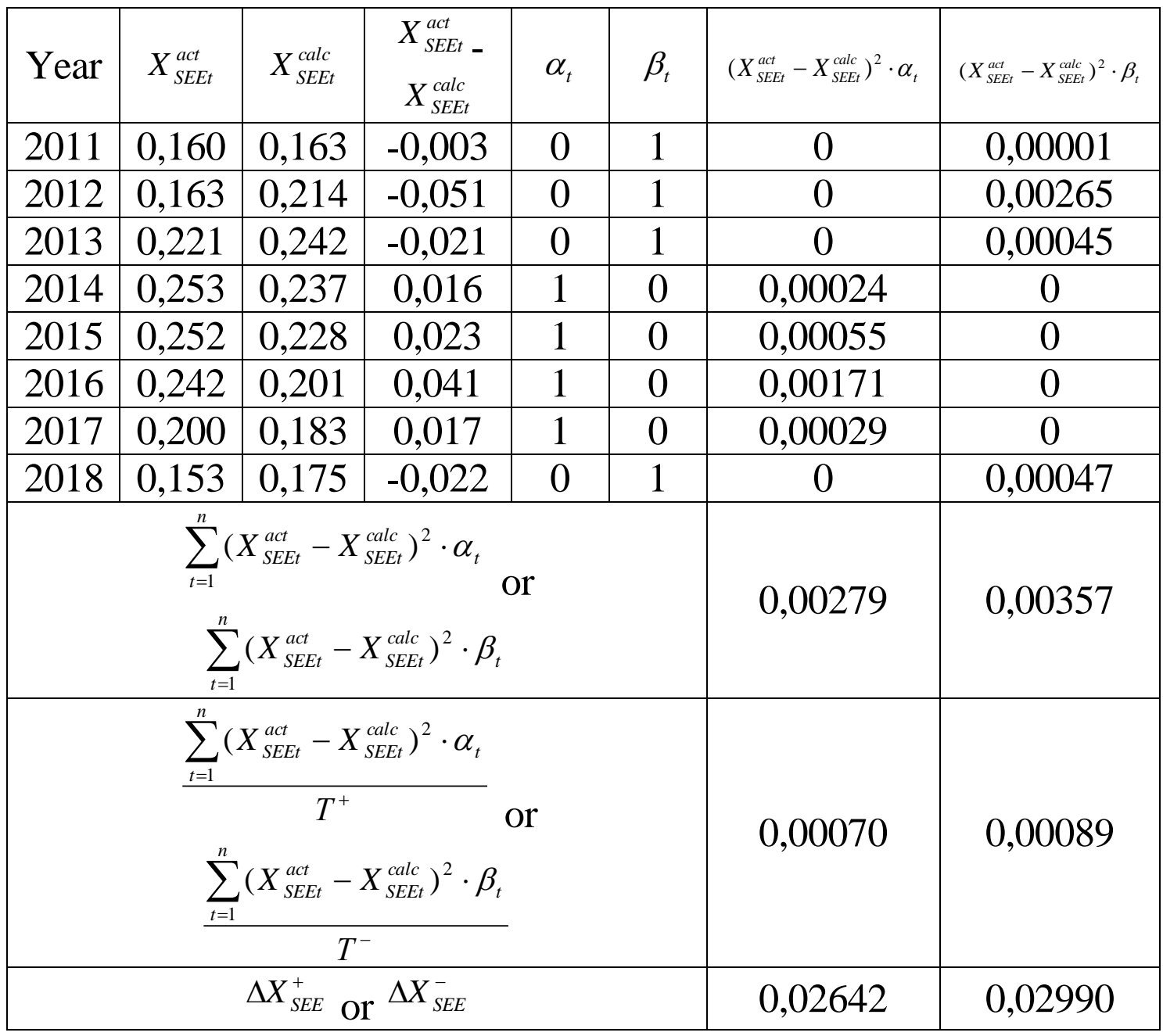

Source: created by the author

As we can see from the data of the table in the four years, the period under review shows an excess of the actual value of the integral indicator of the development of the national economy over the estimated one. Other years are characterized by excess of the estimated value of the 
integral indicator of the national economy development over the actual one.

The reaction time measures evaluation of adaptation to the positive changes and evaluation of adaptation to the negative changes. At the same time, evaluation of adaptation to the positive changes is characterized by the duration of the period of growth of the integral index of development of the national economy $\left(P^{+}\right)$, and evaluation of adaptation to the negative changes is characterized by the duration of the period of decline of the integral index of development of the national economy $\left(P^{-}\right)$. The longer the period of growth and the shorter the period of decline of the integral index, the greater the adaptability of the system.

On the basis of partial indicators of the adaptability evaluation of the national economy to the impact of the external environment, general evaluation indicators are calculated:

1. Reactivity index for system reactivity.

2. Reaction time index.

Reactivity index of the system reactivity is calculated by the formula:

$$
I_{r}=\frac{\Delta X_{S E E}^{+}}{\Delta X_{S E E}^{-}},
$$

where $I_{r}-$ index of adaptability of the national economy by its reactivity;

$\Delta X_{S E E}^{-}$- average negative deviation of the actual value of the integral indicator of the development of the national economy from the calculated value of this indicator;

$\Delta X_{S E E}^{+}$- average positive deviation of the actual value of the integral indicator of the development of the national economy from the calculated value of this indicator.

The reactivity index of the national economy is:

$$
I_{r}=\frac{0,02642}{0,02990}=0,884
$$

It is proposed to determine the adaptability index of the national economy by the formula:

$$
\operatorname{Irt}=\frac{P^{+}}{P^{-}},
$$

where $I r t$ - index of adaptability in reaction time of the national economy to the changes in the environment; 
$P^{+}-$duration of the period of growth of the integral index of development of the national economy;

$P^{-}-$duration of the period of decline of the integral index of development of the national economy.

Considering that for the analyzed period the average duration of the decline of the integral index of development of the national economy is four years, and the average duration of the period of growth - three years, adaptability index for the reaction time of the national economy will be:

$$
I_{r t}=\frac{3}{4}=0,75
$$

The integral index of adaptability of the national economy is proposed to be determined by the formula:

$$
I_{a}=\frac{I_{r}+I_{r t}}{2},
$$

where $I_{a}$ is the integral index of adaptability of the national economy to the influence of external factors;

Ir - index of adaptability of the national economy by its reactivity;

$I r t$ - index of adaptability in reaction time of national economy to the changes in the environment.

It is proposed to interpret the value of the integral index of adaptability of the national economy to the changes in the environment using the following scale:

- $I_{a}>1-$ sufficient adaptability;

- $I_{a}=1$ - normal adaptability;

- $I_{a}<1$ - low adaptability.

According to our calculations, the integral index of adaptability of the national economy is:

$$
I_{a}=\frac{0,884+0,750}{2}=0,817
$$

The value of the integral index of adaptability of the national economy is lower than one, which indicates that the national economy is not sufficiently adaptable to the changes in the external environment.

\section{CONCLUSIONS}

Based on the analysis, it has been proved that there are many definitions of the concepts of adaptation and adaptability, which 
indicates the versatility of their use. It has been determined that adaptability should be used as a characteristic of the national economy, which is necessary to determine the nature and adequacy of the structural change. Against this background, adaptation will be considered as the process necessary to ensure the effective functioning of the national economy and its structural elements in the new environment, oriented towards the constant change of the aggressive external environment. The proposed methodological approach allows us to evaluate the adaptability of the national economy. It involves the use of the combination of scientific methods of evaluation, which make it possible to draw objective conclusions about the current level of adaptability of the national economy and to determine possible changes in the future.

\section{SUMMARY}

The purpose of this study is to develop a methodological approach to the adaptability evaluation of the national economy, taking into account its reactivity and reaction time, and practical testing. As a result of the analysis of the existing works of different scientists it has been established that in any way the concept of adaptation is considered, it is always some change which ultimate purpose is to ensure the effective functioning of the system in the new conditions. Unlike adaptation, the key words in determining adaptability are property, reaction, ability, characterization. It has been proved that adaptability is closely linked to the availability of adaptive capabilities, which in the context of socioeconomic systems theory can be defined as stable resistant characteristics of the national economy, which ensure its ability to adapt to various environmental changes successfully, directing its development. On this basis, our own definition of the concept of adaptability has been formulated.

Methodological approach to adaptability evaluation of the national economy has been developed, which, unlike others, is based on the use of indices by the criteria of reactivity and reaction time, allowing not only to identify the ability of the national economy to resist threats and to use opportunities, adapt to negative and positive changes, but also to give evaluation of the adaptability of the national economy to the influence of the changing environmental factors.

\section{REFERENCES:}

1. Kaznacheev V.P. (1974). Nekotoryie mediko-biologicheskie voprosyi adaptatsii cheloveka. Mediko-biologicheskie problemyi 
adaptatsii naseleniya v usloviyah Kraynego Severa [Some biomedical issues of human adaptation]. Novosibirsk, pp. 3-13.

2. Lastaev T.T. (2006). Mehanizm agropromyishlennoy integratsii [The mechanism of agricultural integration]. Vestnik $K A S S U$, no. 4, pp. 10-12.

3. Miloslavova I.A. (1974). Ponyatie i struktura sotsialnoy adaptatsii : avtoref. dis. ... kand. fil. nauk: spets. 09.00.00 «Sotsialnaya filosofiya» [The concept and structure of social adaptation: author. dis. ... cand. Phil. Sciences: special. 09.00.00 «Social Philosophy»]. Leningrad, $24 \mathrm{p}$.

4. Chizhenkova E.V. (2006). Formirovanie ekonomicheskogo mehanizma adaptatsii hozyaystvuyuschego sub'ekta k ryinochnoy srede: avtoref. dis. ... kand. ekon. nauk : spets. 08.00.01 «Ekonomicheskaya teoriya» [Formation of an economic mechanism for the adaptation of an economic entity to a market environment: author. dis. ... cand. econ. Sciences: special. 08.00.01 "Economic Theory"]. Moskva, 24 p.

5. Pitaykina I.A. (2006). Zakonomernosti razvitiya gosudarstvennyih unitarnyih predpriyatiy Rossii $\mathrm{V}$ ryinochnoy ekonomike: avtoref. dis. ... kand. ekon. nauk : spets. 08.00.01 «Ekonomicheskaya teoriya» [Patterns of development of state unitary enterprises of Russia in a market economy: author. dis. ... cand. econ. Sciences: special. 08.00.01 "Economic Theory"]. Penza, 23 p.

6. Yachmeneva V.M. (2008). Ponyatie «adaptatsiya» i «adaptivnost»: shodstvo i razlichie [The concepts of "adaptation" and "adaptability": similarities and differences]. Nauchnyiy vestnik Poltavskogo universiteta potrebitelskoy kooperatsii Ukrainyi, no. 1 (26), pp. 97-103.

7. Pastuhova E.A. Adaptatsiya ekonomicheskoy sistemyi $\mathrm{k}$ izmeneniyam vneshney sredyi. Mezhdunarodnyiy institut A. Bogdanova. Vserossiyskaya Internet-konferentsiya [Adaptation of the economic system to changes in the external environment. International Institute of A. Bogdanov. All-Russian Internet Conference]. URL: www.bogdinst.ru.

8. Kozachenko G.V. Ponomarov V.P., Lyashenko O.M. (2003). Ekonomicheskaya bezopasnost predpriyatiya: suschnost i mehanizm obespecheniya: monografiya [The economic security of the enterprise: the nature and mechanism of support: a monograph]. Kiev : Libra, 280 p.

9. Hanaliev G.I. (2005). Adaptatsionnyiy protsess avtotransportnyih predpriyatiy [Adaptation process of motor transport enterprises. Stavropol]. Dep. VINITI RAN, № 1122-V, pp. 115-121. 
10. Sudarieva A.Ia. (2007). Velykyi yurydychnyi slovnyk. 3-tie vyd., dop. i pererab [Great Legal Dictionary. 3rd ed., Suppl. and processing]. Moskva: INFRA-M, $858 \mathrm{p}$.

11. Rayzberg B.A., Lozovskiy L.Sh., Starodubtseva E.B. (2006). Sovremennyiy ekonomicheskiy slovar [Modern economic dictionary]. Moskva: Infra-M, 564 p.

12. Danilov-Danilyan V.I. (2003). Ekonomiko-matematicheskiy entsiklopedicheskiy slovar [Economic-mathematical encyclopedic dictionary]. Moskva: Bolshaya Rossiyskaya Entsiklopediya. Moskva: Izdatelskiy Dom «INFRA-M», 688 p.

Information about the author: Kononova I. V. Doctor of Economic Sciences, Department of Accounting, Economics and Personnel Management of Enterprise, Prydniprovska State Academy of Civil Engineering and Architecture, Ukraine 